\title{
PATHOGENICITY OF Candida krusei AND Candida albicans IN THE TONGUE OF RATS
}

\author{
E. DORKO ${ }^{1}$, M. ZIBRÍN ${ }^{2}$, E. PILIPČINEC ${ }^{3}$, A. JENČA ${ }^{4}$, J. JAUTOVÁ ${ }^{5}$, F. DORKO ${ }^{6}$, J. DANKO ${ }^{7}$, \\ E. ŠVICKÝ ${ }^{8}$, I. BRAČOKOVÁ ${ }^{1}$
}

${ }^{1}$ Department of Physiology, Medical Faculty, Šafárik University, Košice; ${ }^{2}$ Department of Histology, University of Veterinary Medicine, Košice; ${ }^{3}$ Department of Microbiology and Immunology, University of Veterinary Medicine, Košice; ${ }^{4}$ Department of Stomatology and Maxillofacial Surgery, Medical Faculty, Safárik University, Košice; ${ }^{5}$ Department of Dermatology, Medical Faculty, Šafárik University, Košice; ${ }^{6}$ Department of Anatomy, Medical Faculty, Šafárik University, Košice; ${ }^{7}$ Department of Anatomy, University of Veterinary Medicine, Košice; ${ }^{8}$ Department of Pathology, University of Veterinary Medicine, Košice, Slovakia

\author{
Received November 11, 2000 \\ Accepted May 28, 2001
}

\section{Abstract}

Dorko E., M. Zibrín, E. Pilipčinec, A. Jenča, J. Jautová, F. Dorko, J. Danko, E. Švický, I. Bračoková: Pathogenicity of Candida krusei and Candida albicans in the Tongue of Rats . Acta Vet. Brno, 2001, 70: 173-177.

The aim of the present study was to compare the potential of Candida krusei and C. albicans to colonize and infect the oral mucosa in a conventional rat model. Thirty adult female SpragueDawley rats were inoculated orally with $0.1 \mathrm{ml}$ of yeast suspension $\left(3.10^{8} \mathrm{cfu} / \mathrm{ml}\right)$. After 3 weeks of inoculation, all the animals were killed using ether anaesthesia. Histological sections of tongues were stained with PAS and Grocott's staining. Characteristic histological changes of mucosal candidosis were discernible on the lingual mucosa of rats infected with C. albicans and C. krusei including parakeratosis, microabscess formation and polymorph infiltration of the lingual epithelium. Although both species produced fungal hyphae that penetrated the epithelium, C. albicans hyphae tended to be relatively more profuse. The study indicated the better ability of C. albicans to colonize and infect the oral mucosa compared with C. krusei. The aetiological role of Candida spp. in the progress of oral mucosal lesions to carcinoma postulated. Therefore, this animal model can constitute a suitable device for validating this hypothesis.

Oral candidosis, rat tongue, Candida albicans, Candida krusei

The role played by various Candida species in initiating oral epithelial lesions is ill understood. Cawson and Lehner (1968) first suggested a possible aetiological relationship between leukoplakia and candidal infection on finding mycelial elements of Candida albicans infiltrating the cornified layer of the epithelium in some cases of human oral leukoplakia (Cawson and Lehner 1968). But others authors have regarded $C$. albicans as a secondary invader rather than the cause of the leukoplakia in those cases in which it is found (Shear 1972). Candida spp. have been identified in as many as $31 \%$ of biopsied leukoplakias, but it has not been clear which changes are due to candidal infection and which are due to other factors in studies using human material (Barrett et al. 1998). Since then several workers have attempted to produce lesions resembling human oral leukoplakia in cultured tissue, chick chorioallantoic membrane and animal models (Partridge 1959). Jones and Russel $(1974,1975)$ pioneered these animal studies and demonstrated histological changes similar to the human disease in the posterior dorsum of the tongue of Sprague-Dawley rats chronically infected with Candida spp. Since then, the Sprague-Dawley rat has served as one of the more useful animal models for investigating the epithelial changes caused by Candida spp. in the oral cavity (Jones and Ru s s ell 1974; Russell and Jones 1975). However, the data from the latter studies almost exclusively pertain to $C$. albicans, the most virulent of the Candida spp. The most commonly 
encountered commensal, a pathological fungus of the oral cavity, is C. albicans, which may exist as a yeast or in a hyphal form. The consensus view is that the former represents the morphotype in health, whereas the latter is pathogenic, although the yeast cells are capable of producing disease via toxin and metabolite synthesis and hyphae can be identified in the mouths of healthy individuals. Although hyphae do not always pierce the epithelium, penetration of the cell membrane and occupation of the cytoplasm may either produce clinical entities which are readily recognisable, or subclinical infection which is only detected after biopsy and microscopic examination. A histopathological report of unexpected fungal infection is likely to be acted on clinically and may affect the patient's management and prognosis (B arrett et al. 1998). There is sparse information on the less pathogenic species of Candida such as C. krusei, C. parapsilosis, and C. tropicalis.

Therefore, the aim of the present study was to compare the potential of $C$. krusei and $C$. albicans to colonize and infect the oral mucosa in a conventional Sprague-Dawley rat model.

\section{Materials and Methods}

The strains of $C$. albicans and $C$. krusei were isolated from oral lesions of denture stomatitis patients and were simply designated strain I, II, III (C. albicans), IV,V and VI (C. krusei). Each isolate was identified as C. albicans and $C$. krusei by means of microscopic appearance, colony morphology on Sabouraud's agar (fy Imuna, Slovakia) and CHROMagar Candida (Mast Diagnostica, France), chlamydospore formation, sugar assimilation and fermentation, and germ tube formation within $2 \mathrm{~h}$ after inoculation of the yeast phase into human serum with incubation at $37^{\circ} \mathrm{C}$ (Allen and Beck 1987).

Seventy-two hours prior to the inoculation of the rats, each strain was streaked on individual slants of mycological agar and allowed to incubate at room temperature $\left(23^{\circ} \mathrm{C}\right)$. On the day of inoculation, the yeasts were washed from the slants with sterile saline, centrifuged at 2500 r.p.m. for $10 \mathrm{~min}$, and resuspended in a concentration of $3.10^{8} \mathrm{cfu} / \mathrm{ml}$ (Allen and Beck 1983, 1987; Allen et al. 1989; Bykov 1991).

The experiment was carried out on 30 female Sprague-Dawley rats of conventional microbial quality with a body weight $200 \pm 50 \mathrm{~g}$. Before the experiment, the animals were reared in the Central Animal Husbandry quarters under veterinary care. They were housed in steel cages, five animals per cage, in groups $1-6$ and kept under standard conditions (air temperature $22 \pm 2{ }^{\circ} \mathrm{C}$; relative humidity $55 \pm 5 \% ; 10-15$ of air exchanges per hour; illumination 350 lux; controlled light regimen $12+12$ h LD; conventional housing) and supplied the Larsen diet (Dobrá Voda, Czech Republic).

The oral cavity of each rat was swabbed with a sterile cotton-tipped applicator which was immediately placed on a Sabouraud agar plate for a presumptive identification of yeasts (Allen et al. 1989). No animal was found to harbour the yeast intraorally at the start of the experiment.

Each group of rats (group 1-3) received a particular strain of C. albicans (strains I, II, III) and each group of rats (group 4-6) received a particular strain of C. krusei (strains IV, V, VI). All rats were inoculated orally with $0.1 \mathrm{ml}$ of the yeast suspension $\left(3.10^{8} \mathrm{cfu} / \mathrm{ml}\right)$, by means of a syringe fitted with a blunt 25 -gauge needle, three times per week over the 3-week experimental period (S a maranayake et al. 1998).

Following 3 weeks of inoculation, all animals were killed under ether anaesthesia. The tongues were surgically exposed. The tissue was then immersed in $10 \%$ buffered formalin, allowed to fix for at least $48 \mathrm{~h}$. Histological sections were cut at $6 \mu \mathrm{m}$ and stained with PAS and Grocott's staining (Allen and Beck 1987; Mechírová et al. 1995).

\section{Results}

None of the Sprague-Dawley rats in the six designated groups was colonized by Candida spp. at the beginning of the experiment. At the end of week 1, after three inoculations, both species, $C$. albicans and $C$. krusei, were recovered from the oral cavities of all animals.

White patches on the dorsal tongue mucosa were evident, with depapillation of the conical papillae region and smooth erythematous areas anterior and posterior to this region. The diameter of the lingual lesional areas was $3 \mathrm{~mm}$. Histopathological changes of tissue sections incorporating the white patches demonstrated a loss of normal lingual papillae and replacement by a smooth layer of parakeratotic and acanthotic epithelium. The superficial layers of epithelium showed marked intercellular and intracellular oedema with polymorph infiltration. The corium showed slightly increased vascularity and mild oedema with scanty infiltrate of mononuclear cells. 
Stained sections showed hyphal infiltration of the cornified layers by C. krusei which were generally shorter than those $C$. albicans, and penetrated a relatively short depth of the keratinised epithelium. The number of hyphae penetrating the oral epithelium was relatively fewer and more sparsely distributed for C. krusei than with $C$. albicans. C. albicans hyphae penetrating the oral epithelium appeared in clusters on the lingual epithelium, compared with isolated, individual hyphae in the case of $C$. krusei (Plate VI, Fig. 1, 2). In some areas no host response was seen, while in other areas microabscess had formed in the keratin layer and the superficial spinous layer of the epithelium. Microabscesses in the keratin and the superficial spinous layers were seen only in association with hyphal invasion. PAS method demonstrated purple yeast cells in loose connective tissue (Plate VII, Fig. 3, 4).

The most important finding was necrosis of musculature in the application place. It had caseous and local character, without an epithelioid rim formation in the surroundings. Granular tissue formation was present as a sign of reparation. Margins of necrosis were sharply delineated.

The skeletal muscle fascicles immediately subjacent to the infected epithelium showed striking degeneration and atrophy associated with a marked infiltrate of chronic inflammatory cells.

\section{Discussion}

Candida spp. are responsible for a wide spectrum of diseases, ranging from superficial mucosal infection to fatal systemic involvement. The most common form of oral candidosis is erythematous candidosis (syn. chronic atrophic candidosis) ( $\mathrm{O}^{\prime} \mathrm{Grady}$ and Reade 1993).

Attempts to analyse candidal strain-related differences in human disease have generally not been successful, and this failure is undoubtedly due to the complex nature of both exogenous and endogenous factors affecting human candidosis. Thus, the clinical presentation of the disease could be influenced by any one of the several factors, such as host immune status, diet, salivary flow rate and salivary composition, endocrine disturbances, use of antibiotics or steroids, and the presence of dentures (Allen and Beck 1987). These factors are eliminated in experiment and also our animal model is a suitable tool for detection of pathogenicity of yeast microorganisms.

Candidosis of the dorsal rat tongue has been reported by Allen et al. (1983, 1987, 1989), Jones and Russel $(1974,1975)$ as a characteristic, clinically apparent, lesion in the gigant conical papillae region. This clinical lesion was observed in $70 \%$, and infection with Candida spp. was confirmed histologically.

Our results obtained from the animals inoculated with $C$. albicans and $C$. krusei only were similar to those described by Jones and Russell (1974, 1975), indicating that their model had been successfully reproduced and that experimental candidal infection in rats produced changes in the histomorphology of the dorsal lingual epithelium. Following inoculation, the organism in its hyphal form first penetrated the keratin layer of normal orthokeratotic epithelium with associated hyperplastic and inflammatory changes. Despite the increased morbidity caused by $C$. krusei, the approaches used in the investigation of mucosal candidosis have focused mainly on the most virulent species, $C$. albicans, and to our knowledge there are no animal studies pertaining to oral $C$. krusei infection. It would appear that this is the first documented study on the oral carriage of $C$. krusei in an animal model (in addition to Samaranayake et al. 1998). Samaranayake et al. (1998) indicated that C. kruse i isolates were able to colonize the rat tongue mucosa, but in smaller numbers than C. albicans, despite the use of equal inocula at an identical frequency and the same conditions. The lower oral carriage of $C$. krusei, in general, may reflect its reduced ability to adhere to buccal epithelial cells when compared with $C$. albicans. 
In conclusion, Candida spp. are typical commensal organisms found on the surface of the organs (oesophagus, oral cavity), and their population is known to increase dramatically in immunodeficient hosts. Moreover, pathological studies have demonstrated that deep invasive lesions of mucosal membranes and of the oesophagus in particular, frequently serve as a source of a haematogenous spread of Candida infection (B y kov 1991).

Candida spp. have a similar ability to promote neoplastic changes ( $\mathrm{O}^{\prime} \mathrm{Grady}$ and Reade 1992). An aetiological role for Candida in causing the progression of oral mucosal lesions to carcinoma was suggested by Cawson in 1966 and has been a controversial point since that time.

The pathological significance of fungal, and particularly candidal infection of the oral mucosa remains unknown, but candidal leukoplakia is regarded as a potentially malignant lesion and infection may be a pivotal factor in the aetiology of oral epithelial neoplasia (B arrett et al. 1998).

Histological methods identify fungal infection where it may not be evident clinically and are the quickest, most reliable means to determine whether there is fungal invasion. On histological confirmation of dysplasia, antifungal therapy should be considered in the management of these lesions.

\section{Patogenita Candida krusei a Candida albicans na jazyku potkana}

Cielom tejto štúdie bolo porovnat schopnost $C$. krusei a $C$. albicans kolonizovat a infikovat sliznicu ústnej dutiny na konvenčnom modeli potkana Sprague-Dawley. Tridsat potkaních samíc Sprague-Dawley boli orálne infikované s $0,1 \mathrm{ml}$ suspenzie kvasiniek $\left(3.10^{8} \mathrm{cfu} / \mathrm{ml}\right)$. Po troch týždňoch zvieratá boli usmrtené éterovou anestézou. Histologické rezy jazykov boli ofarbené metódou PAS a Groccotovým farbením. Histologické zmeny na sliznici jazyka infikovaných potkanov s C. albicans a C. krusei vykazovali parakeratózu, tvorbu mikroabscesov a infiltráciu polymorfonukleárnymi bunkami. Obidva druhy kvasiniek penetrovali epitelom, ale hýfy $C$. albicans sa vyskytovali vo väčších počtoch. V práci sme poukázali na väčšiu schopnost $C$. albicans kolonizovat a infikovat orálne sliznice $\mathrm{v}$ porovnaní s C. krusei. Predpokladá sa etiologická úloha kvasiniek pri transformácii mukóznych lézií v karcinóm a teda tento živočíšny model môže byt vhodným na potvrdenie tejto hypotézy.

\section{References}

ALLEN, C. M., BECK, F. M. 1983: Strain-related differences in pathogenicity of Candida albicans for oral mucosa. J. Infect. Dis. 147: 1036-1040

ALLEN, C. M., BECK, F. M. 1987: Differences in mucosal reaction related to Candida albicans isolates. J. Oral Pathol. 16: 89-93

ALLEN, C. M., PAULSON, R., DUNCAN, R. 1989: Clinical, histologic and scanning electron microscopic study of the development of chronic candidiasis of the rat tongue. J. Oral Pathol. Med. 18: 352-359

BARRETT, A. W., KINGSMILL, V. J., SPEIGHT, P. M. 1998: The frequency of fungal infection in biopsies of oral mucosal lesions. Oral Dis. 4: 26-31

BYKOV, V. L. 1991: Velocity of Candida albicans invasion into host tissues. Mycoses 34: 293-296

CAWSON, R. A. 1966: Chronic oral candidiasis and leukoplakia. Oral. Surg. Oral Med. Oral Pathol. 22: 582-591

CAWSON, R. A., LEHNER, T. 1968: Chronic hyperplastic candidiasis- candidal leukoplakia. Br. J. Dermatol. 80: $9-16$

JONES, J. H., RUSSELL, C. 1974: The histology of chronic candidal infection of the rat's tongue. J. Path. 113: 97-100 MECHÍROVÁ, E., ZACHARIÁS̆, L., BELEJ, K., SZABÓOVÁ, O. 1995: Histology. Tranox, Košice, 167 p.

O'GRADY, J. F., READE, P. C. 1992: Candida albicans as a promoter of oral mucosal neoplasia. Carcinogenesis 13: 783-786

O'GRADY, J. F., READE, P. C. 1993: Role of thermal trauma in experimental oral mucosal Candida infections in rats. J. Oral Pathol. Med. 22: 132-137

PARTRIDGE, B. M. 1959: The use of the chorioallantoic membrane of the developing chick for culture of dermatophytes: a modified technic, a preliminary report upon its use for serial passage. J. Invest. Dermatol. 32: 605-619 
RUSSELL, C., JONES, J. H. 1975: The histology of prolonged candidal infection of the rat's tongue. J. Oral Pathol. 4: 330-339

SAMARANAYAKE, Y. H., WU, P. C., SAMARANAYAKE, L. P., HO, P. L. 1998: The relative pathogenicity

of Candida krusei and C. albicans in the rat oral mucosa. J. Med. Microbiol. 47: 1047-1057

SHEAR, M. 1972: Erythroplakia of the mouth. Int. Dent. J. 22: 460 
Plate VI

Dorko E. et al.: Pathogenicity... pp. 173-177

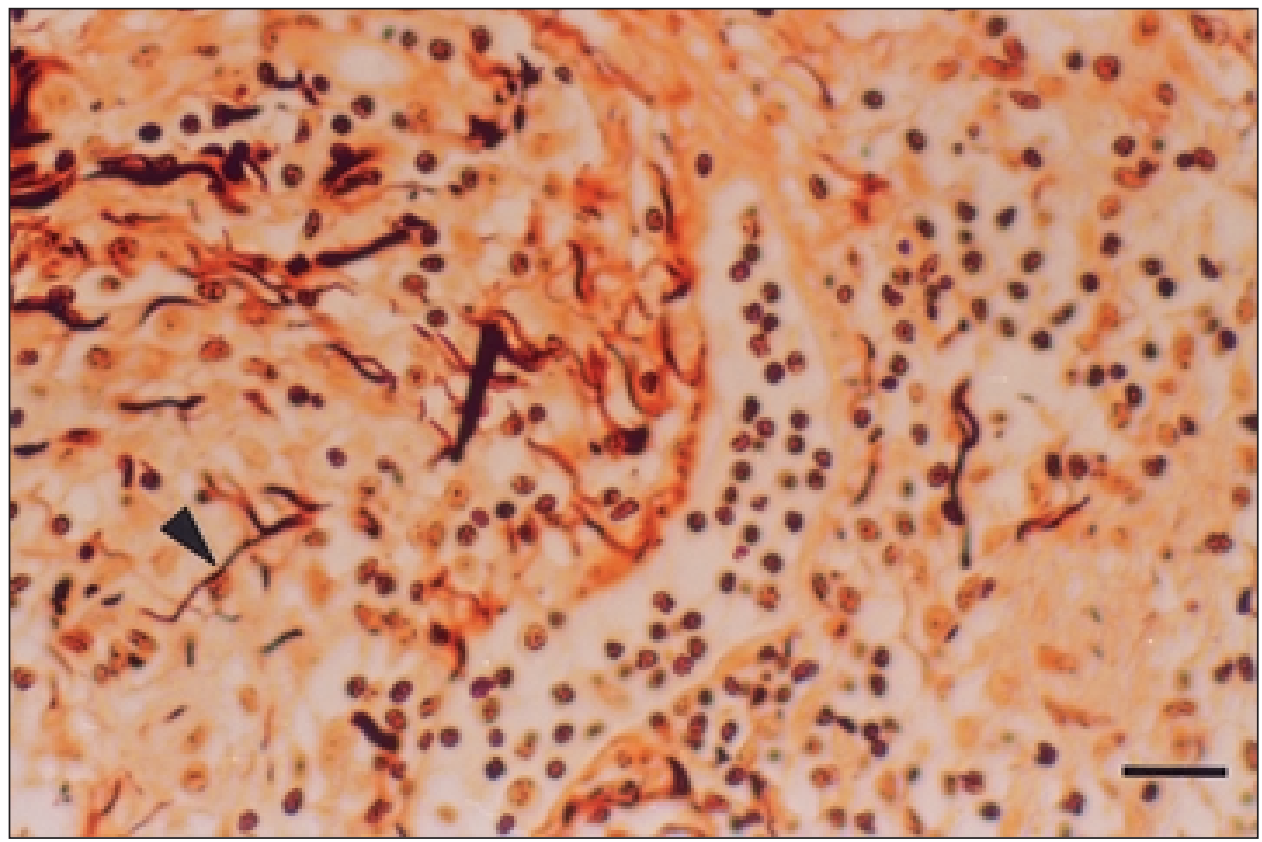

Fig. 1. Candidosis of the rat's tongue. Silver positive hyphae (dark brown or black, arrowhead). Grocott's staining Bar equal to $20.8 \mu \mathrm{m}$.

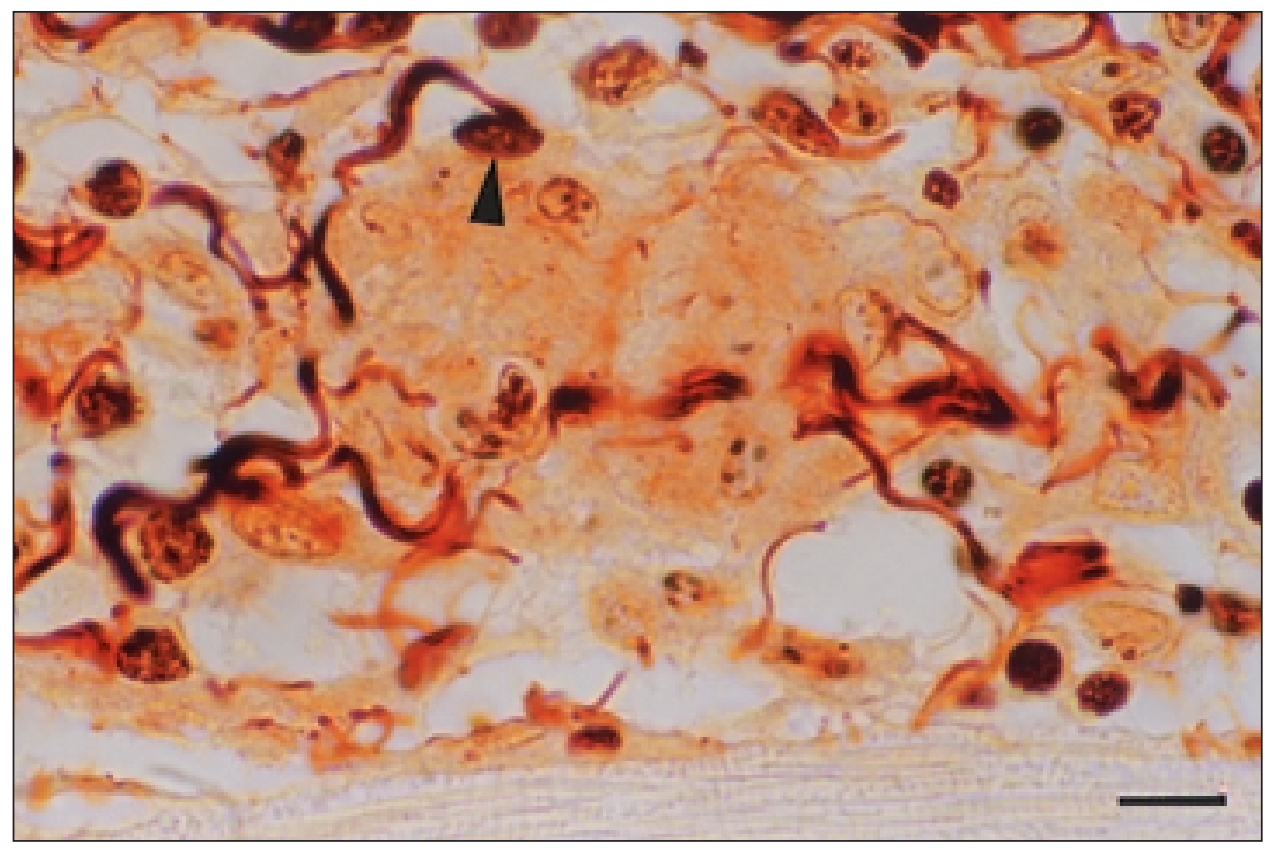

Fig. 2. Candidosis of the rat's tongue. Both yeast cells and hyphae were demonstrated by Grocott's staining. Yeast cell (arrowhead) with germinating hypha. Bar is equal to $8.3 \mu \mathrm{m}$. 
Plate VII

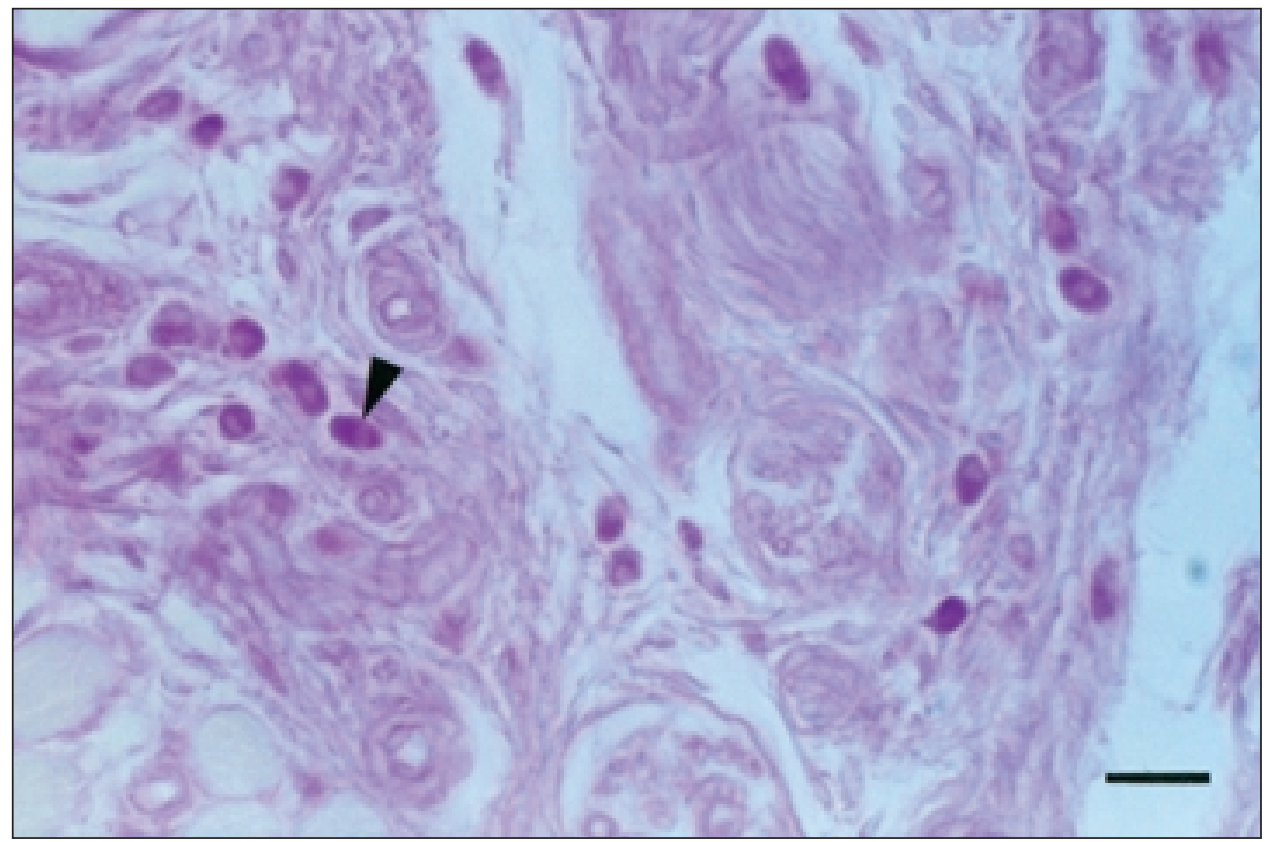

Fig. 3. Candidosis of the rat's tongue. PAS positive yeast cells (purple, arrowhead) in loose connective tissue. Bar is equal to $20.8 \mu \mathrm{m}$

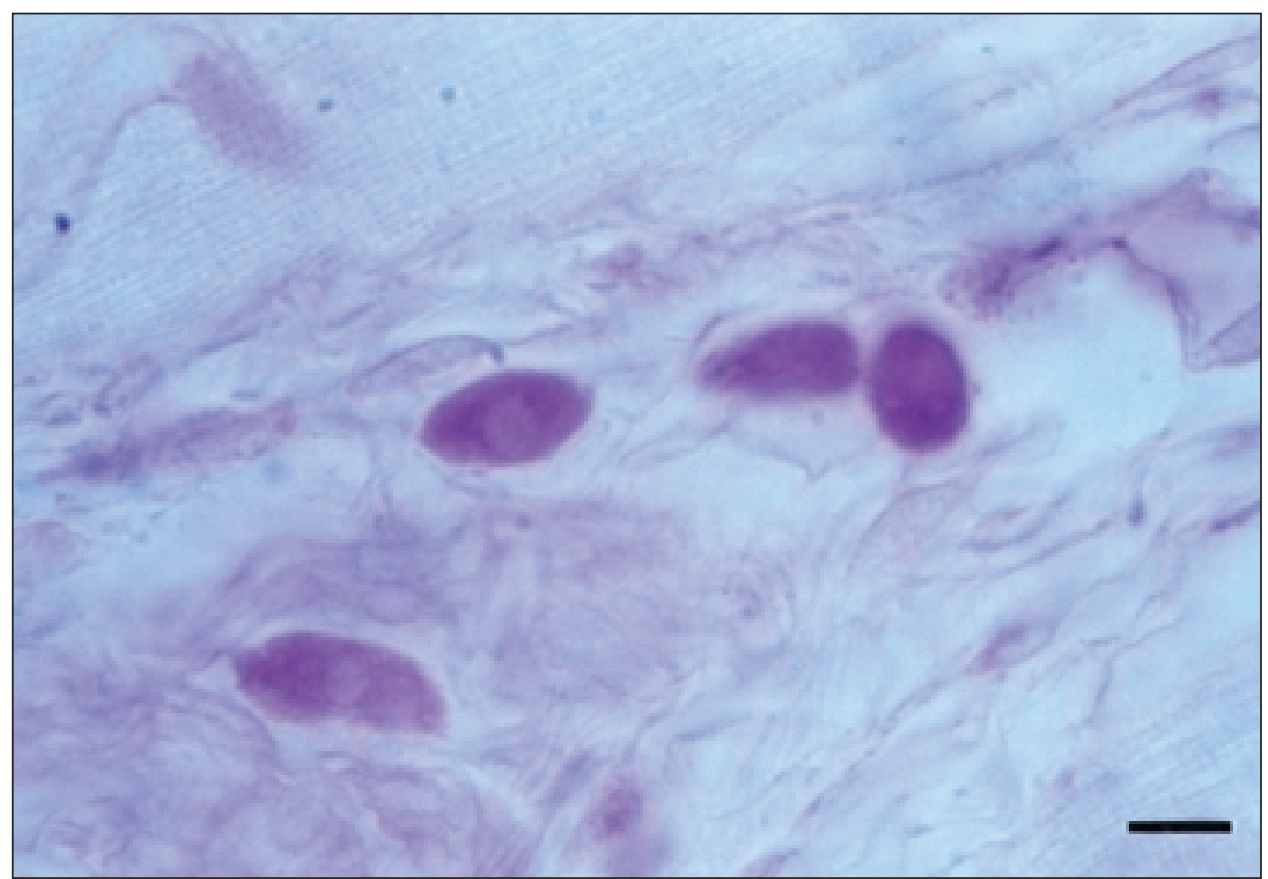

Fig. 4. Candidosis of the rat's tongue. PAS reaction demonstrated yeast cells (dark purple). Bar is equal to $8.3 \mu \mathrm{m}$. 